\title{
Treatment of upper limb lymphedema with low-level laser: a systematic review
}

\author{
Laser de baixa potência no tratamento do linfedema \\ de membro superior: revisão sistemática
}

\author{
Silvia Elizate Monteiro ${ }^{[a]}$, Lilian Valim Resende ${ }^{[b]}$, Mônica Faria Felicíssimo ${ }^{[c]}$, \\ Angélica Rodrigues de Araújo ${ }^{[\mathrm{d}]}$, Camila Teixeira Vaz ${ }^{[\mathrm{e}]}$ \\ [a] Msc, professor at Pontifícia Universidade Católica de Minas Gerais (PUC Minas), Belo Horizonte, MG - Brazil, e-mail: \\ silviaelizate@gmail.com \\ [b] PhD, Universidade Federal de Minas Gerais (UFMG), Belo Horizonte, MG - Brazil, e-mail: lilianvalim@hotmail.com \\ [c] Phd student, professor at Pontifícia Universidade Católica de Minas Gerais (PUC Minas), Belo Horizonte, MG - Brazil, \\ e-mail: mfelicissimo@terra.com.br \\ [d] PhD, professor at Pontifícia Universidade Católica de Minas Gerais (PUC Minas), Belo Horizonte, MG - Brazil, e-mail: \\ angelica@bios.srv.br \\ [e] Msc, Universidade Federal de Minas Gerais (UFMG), Belo Horizonte, MG - Brazil, e-mail: milatvaz@yahoo.com.br
}

\begin{abstract}
Introduction: Low-level lasers have been suggested as a complement to lymphedema treatment. However, this therapy's mechanism of action and its effects are poorly understood up to the present. Objective: To conduct a systematic literature review to analyze the effects of low-level laser in the treatment of upper-limb lymphedema in women submitted to breast cancer surgery. Material and methods: Randomized clinical trials were included, in Portuguese, English and Spanish, from January 1990 to July 2013. The article search was carried out in the Pubmed, Lilacs and PEDro electronic databases, with the following descriptors: Terapia a Laser de Baixa Intensidade, Linfedema, Câncer de Mama, Low-level laser therapy, Lymphedema, Breast Neoplasms and also through a manual search. Results and discussion: Low-level lasers have been used for treating several acute and chronic conditions. However, its application for managing post breast cancer surgery is still recent, often based on empirical evidence. Treating upper-limb lymphedema with low-level laser presented positive results, with reduction in the circumference or volume of the affected
\end{abstract}


limb. Conclusion: More studies of high methodological quality are needed in order to better understand the mechanism of action of low-level laser on the lymphatic system and its effects on lymphedema treatement.

Keywords: Low-level laser therapy. Lymphedema. Breast neoplasms.

\section{Resumo}

Introdução: O Laser de baixa potência vem sendo sugerido como uma forma complementar ao tratamento do linfedema. Entretanto, os mecanismos de ação dessa terapêutica bem como seus efeitos são pouco esclarecidos até o momento. Objetivo: Realizar uma revisão sistemática da literatura, a fim de analisar os efeitos do laser de baixa potência no tratamento de linfedema de membro superior em mulheres submetidas à cirurgia do câncer de mama. Materiais e métodos: Foram incluídos ensaios clínicos aleatorizados nos idiomas português, inglês e espanhol, de janeiro de 1990 a julho de 2013. A busca dos artigos foi realizada nas bases de dados eletrônicas Pubmed, Lilacs e PEDro, utilizando os seguintes descritores: Terapia a Laser de Baixa Intensidade, Linfedema, Câncer de Mama, Low-level laser therapy, Lymphedema, Breast Neoplasms e também por meio da busca manual. Resultados e discussão: $O$ Laser de baixa potência tem sido utilizado no tratamento de vários problemas agudos e crônicos. Porém, sua aplicação para o manejo do linfedema pós cirurgia de câncer de mama ainda é recente, sendo essa muitas vezes embasada em evidências empíricas. O tratamento do linfedema de membro superior com o laser de baixa potência apresentou bons resultados, com uma redução da circunferência ou volume do membro acometido. Conclusão: Mais estudos, de alta qualidade metodológica, são necessários para um maior entendimento do mecanismo de ação do laser de baixa potência sobre o sistema linfático e seus efeitos no tratamento do linfedema.

Palavras-chave: Terapia a laser de baixa intensidade. Linfedema. Câncer de mama.

\section{Introduction}

For decades, women affected by breast cancer were treated only with classical radical mastectomy, in which the breast, thoracic wall muscles and axillary lymph nodes are completely removed (1). However, in the last 20 years, these women's treatment has evolved considerably with the advent of more conservative techniques. These methods are based on tumor excision with wider (quadrantectomy) or more limited (tumorectomy) margins of safety, associated with axillary lymph node dissection and radiotherapy. They present similar results regarding these women's survival rates and are more beneficial in aesthetic and psychological terms when compared to radical mastectomy (2).

Despite all the advancements related to breast cancer prognosis, diagnosis and treatment, complications due to the latter, such as nerve injury, seromas, pain, shoulder disfunction and upper-limb lymphedema are significant (3), as they interfere directly with women's quality of life $(4,5)$.
Lymphedema following breast cancer surgery is a particularly significant complication, for it results in pain and discomfort for the patient, increases risk of infection, problems with body image and can generate negative impacts on different dimensions of women's functionality, including the physical, social and mental areas (6). Furthermore, it is highly prevalent, affecting approximately $30 \%$ of breast cancer patients (7).

Lymphedema is characterized as a chronic edema due to insufficiency of the lymphatic system, damaged primarily by axillary lymph node dissection and radiotherapy (7). These procedures, which are often fundamental in the treatment of neoplasms, cause altered lymph flow $(5,8)$.

Currently, there is a variety of therapeutic options for upper-limb lymphedema, divided into surgical methods and conservative treatments (9). The latter includes medication, psychological rehabilitation and physical therapy (9). Complete decongestive therapy, intermittent pneumatic compression (IPC), manual lymphatic drainage, compression and elastic bandages 
are all resources that compose the physical therapy approach (9). Complete decongestive therapy is one of the most commonly used resources, currently considered the gold standard for lymphedema treatment (9). This technique combines skin care, manual lymphatic drainage, compression or elastic bandages and lymph myokinetic exercises for the upper limbs.

Since the 1990s, low-level laser therapy (LLLT) has been suggested as a complement to lymphedema treatment (10-12). Therapeutic light in the red to near-infrared spectral range is believed to stimulate lypmhangiogenesis, motricity of the lymphatic system (13-15), action of macrophages and the immune system $(16,17)$, and reduce lymphostatic fibrosis (13-15). However, this therapy's mechanism of action and its effects are poorly understood up to the present.

Thus, the objective of this study was to conduct a systematic literature review to analyze the effects of low-level laser on upper-limb lymphedema treatment in women submitted to surgical breast cancer treatment. Specifically, the actions of this therapeutic resource in reducing lymphedema and pain modulation were investigated.

\section{Materials and methods}

Search strategies

A bibliographical search was undertaken between August 2011 and August 2013 in three electronic databases: Pubmed, PEDro and Lilacs. The following key words were combined: "Terapia a Laser de Baixa Intensidade", "Linfedema"; "Câncer de Mama"; "Lowlevel Laser Therapy"; "Lymphedema"; "Breast Neoplasms". Table 1 presents the combinations of key words used to search electronic databases. In addition to electronic databases, the authors also searched the literature manually, based on the bibliography of the previously selected articles.

\section{Inclusion criteria}

Type of study

This review included experimental studies in Portuguese, English or Spanish, published between January 1990 and July 2013.

\section{Participants}

Selection criterion was applied to studies conducted with women who, following breast cancer surgery, presented upper-limb lymphedema for different periods of time.

\section{Intervention}

Studies that used low-level laser as a form of lymphedema treatment, with or without the use of other techniques, were included.

Table 1 - Literature search protocol in Pubmed, PEDro and Lilacs databases

\begin{tabular}{ll}
\hline \multicolumn{1}{c}{ Database } & \multicolumn{1}{c}{ Keywords } \\
\hline Pubmed and PEDro & 1. low-level laser therapy \\
& $\begin{array}{l}\text { 2. low-level laser therapy AND breast neoplasms } \\
\text { 3. low-level laser therapy AND lymphedema }\end{array}$ \\
& $\begin{array}{l}\text { 4. low-level laser therapy AND breast neoplasms AND } \\
\text { lymphedema }\end{array}$ \\
\hline Lilacs & $\begin{array}{l}\text { 1. terapia a laser de baixa intensidade } \\
\text { 2. terapia a laser de baixa intensidade AND câncer de mama }\end{array}$ \\
& $\begin{array}{l}\text { 3. terapia a laser de baixa intensidade AND linfedema } \\
\text { 4. terapia a laser de baixa intensidade AND câncer de mama AND } \\
\text { linfedema }\end{array}$ \\
\hline
\end{tabular}




\section{Exclusion Criteria}

Quasi-experimental and comparative studies with no control group were excluded from this review.

Data extraction and methodological quality

Studies were selected by two independent reviewers (CTV and SEM). Two additional independent reviewers (ARA and MFF) performed data extraction from the articles and assessed their methodological quality using the PEDro scale (Physiotherapy Evidence Database) (18). In case of divergent scores, the opinion of a third person (LVR) was included in order to reach a consensus.

According to the PEDro scale, studies that scored below 4 were considered methodologically weak; studies that scored between 5 and 7 were considered of fair quality and those that scored 8 or higher (8 to 10 points) possessed high methodological quality (18).

\section{Analysis of laser parameters}

Analysis of laser parameters used in the selected studies was conducted according to the recommendations set forth by Jan Tunér and Lars Hode, published in 2004 (19).

\section{Analysis of results}

Information regarding sample size, comparison groups, investigated outcomes, main results, and the assessment of the selected articles' methodological quality were tabulated to facilitate data analysis and interpretation. The correlation between the study's objective and outcome, explanations of the results and clarity in the determination and description of laser parameters used in each study was verified.

\section{Results}

The electronic databases and manual searches returned only 13 studies that met the inclusion criteria. Of these, eight were from the Pubmed database (10, $12,20,21,22)$, four from the PEDro database (10, $11,23,24)$ and one from the manual search (22). No studies were found in the Lilacs database. Four studies found in the PEDro database were duplicates of those found in Pubmed. Three studies were excluded for being quasi-experimental $(12,21,25)$ and one for being a comparative study with no control group (20). Therefore, this systematic review counted with a total of five studies $(10,11,22,23,24)$. Figure 1 presents a flowchart with the results of the electronic and manual searches.

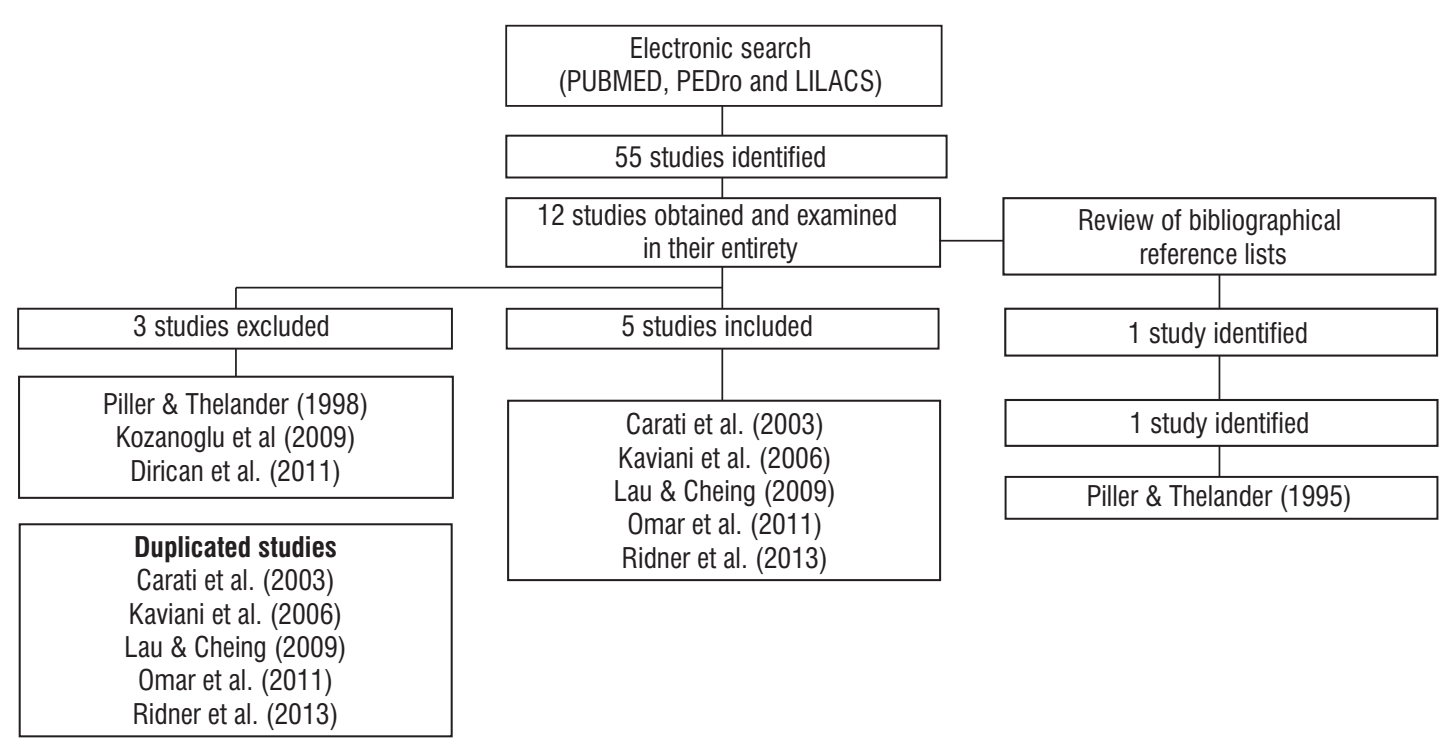

Figure 1 - Results of the database and manual search 
Study characteristics and quality

The articles included in the review were published between 2004 and 2013. In general terms, they presented small samples, varying from 11 to 61 participants. Table 2 illustrates the main characteristics of the five analyzed articles.

Three studies used the volume of the affected limb as the main outcome $(10,22,23)$ and two used its circumference $(11,24)$. The articles that used circumference as their main outcome did not specify what instrument was used to measure it. Carati et al. (10) employed infrared sensors to measure limb circumference and used the truncated-cone model method to calculate volume (10). Lau and Cheing (23) employed direct volumetry. Other studies calculated changes in pre- and post-treatment circumference by finding the difference of the sums between the circumference of the affected limb and of the non-affected limb $(11,23)$. All studies presented positive results for the groups that used active LLLT when compared to control groups. These results were most evident in studies with a longer timeframe $(11,20)$.
Among subjective measures, only one study did not assess symptoms related to lymphedema, such as pain, feeling of tightness, heaviness, cramping, tingling, pricking and perceived improvement in mobility (24).

In addition to the reduction of lymphedema and pain, all articles investigated other outcomes to evaluate indirect effects of LLLT, such as stiffness, shoulder range of motion of the affected limb, distribution of extracellular fluid, participants' perception regarding other lymphedema-related symptoms, ability to carry out specific activities of daily living, overall quality of life and grip strength $(10,11,22$, 23, 24).

All five studies were controlled. Only the study by Ridner et al. (22) did not use a placebo group (inactive laser) as a control in their study. They chose to control the groups using manual lymphatic drainage. It is worth noting, however, that the duration of manual lymphatic drainage differed between groups: the group that received only manual lymphatic drainage was submitted to 40' of the technique, whereas the laser and manual lymphatic drainage group received only $20^{\prime}$ of the technique.

Table 2 - Characteristics of studies that evaluated the effect of LLLT in women with upper-limb lymphedema following breast cancer surgical treatment

(To be continued)

\begin{tabular}{|c|c|c|c|c|}
\hline Author (year) & Sample & Comparison groups & $\begin{array}{l}\text { Main outcomes/ } \\
\text { Instruments }\end{array}$ & Main results \\
\hline $\begin{array}{l}\text { Carati et al. } \\
\text { (2003) }\end{array}$ & 61 & $\begin{array}{l}\text { 1. Group 1: } 1^{\text {st }} \text { part - placebo } \\
\text { LLLT 3x/week, for } 3 \text { weeks; } 2^{\text {nd }} \\
\text { part - active LLLT } 3 x / \text { week, for } \\
3 \text { weeks. } \\
\text { 2. Group 2: } 1^{\text {st }} \text { part - active } \\
\text { LLLT } 3 \text { x/week, for } 3 \text { weeks; } \\
2^{\text {nd }} \text { part - active LLLT } 3 \text { x/ } \\
\text { week, for } 3 \text { weeks. }\end{array}$ & $\begin{array}{l}\text { 1. Volume/Perimeter of } \\
\text { affected limb. } \\
\text { 2. Pain and feeling of } \\
\text { heaviness in affected limb/ } \\
\text { Score } 1 \text { (no symptoms) to } 10 \\
\text { (worst imaginable pain) }\end{array}$ & $\begin{array}{l}\text { Two cycles of LLLT were } \\
\text { significantly effective in } \\
\text { reducing volume of affected } \\
\text { limb in } 31 \% \text { of participants, } 1 \\
\text { month or } 3 \text { months following } \\
\text { treatment. There were no } \\
\text { differences regarding other } \\
\text { outcomes. }\end{array}$ \\
\hline $\begin{array}{l}\text { Kaviani et al. } \\
\text { (2006) }\end{array}$ & 11 & $\begin{array}{l}\text { 1. Group 1: Placebo LLLT } 3 \text { x/ } \\
\text { week, for } 3 \text { weeks. After an } \\
\text { 8-week interval, placebo LLLT } \\
\text { protocol was repeated. } \\
\text { 2. Group 2: Active LLLT } 3 \text { x/ } \\
\text { week, for } 3 \text { weeks. After an } \\
\text { 8-week interval, active LLLT } \\
\text { protocol was repeated. }\end{array}$ & $\begin{array}{l}\text { 1. Circumference/Perimeter of } \\
\text { affected limb } \\
\text { 2. Pain and heaviness } \\
\text { sensation in affected limb/ } \\
\text { Visual Analog Scale. }\end{array}$ & $\begin{array}{l}\text { There was a significant } \\
\text { reduction in affected limb } \\
\text { circumference and pain in } \\
\text { the group that received active } \\
\text { LLLT. There was no difference } \\
\text { regarding feeling of heaviness. }\end{array}$ \\
\hline
\end{tabular}


Table 2 - Characteristics of studies that evaluated the effect of LLLT in women with upper-limb lymphedema following breast cancer surgical treatment

(Conclusion)

\begin{tabular}{|c|c|c|c|c|}
\hline Author (year) & Sample & Comparison groups & $\begin{array}{l}\text { Main outcomes/ } \\
\text { Instruments }\end{array}$ & Main results \\
\hline \multirow[b]{2}{*}{$\begin{array}{l}\text { Lau \& Cheing } \\
\text { (2009) }\end{array}$} & \multirow[b]{2}{*}{21} & $\begin{array}{l}\text { 1. Group 1: Placebo LLLT } 3 \text { x/ } \\
\text { week, for } 4 \text { weeks. }\end{array}$ & $\begin{array}{l}\text { 1. Volume of affected limb/ } \\
\text { Direct volumetry }\end{array}$ & \multirow{2}{*}{$\begin{array}{l}\text { There was a significant } \\
\text { reduction in the volume of the } \\
\text { affected limb at the end of } \\
\text { treatment and in the follow- } \\
\text { up in the active LLLT group. } \\
\text { There were no differences for } \\
\text { any of the other investigated } \\
\text { outcomes. }\end{array}$} \\
\hline & & $\begin{array}{l}\text { 2. Group 2: Active LLLT } 3 \text { x/ } \\
\text { week, for } 4 \text { weeks. }\end{array}$ & $\begin{array}{l}\text { 2. Pain and difficulty carrying } \\
\text { out activities/ Disabilities Arm, } \\
\text { Shoulder and Hand (DASH), } \\
\text { questionnaire. }\end{array}$ & \\
\hline $\begin{array}{l}\text { Omar et al. } \\
\text { (2011) }\end{array}$ & 50 & $\begin{array}{l}\text { 1. Group 1: Placebo LLLT } 3 \text { x/ } \\
\text { week, for } 12 \text { weeks. } \\
\text { 2. Group 2: active LLLT } 3 \text { x/ } \\
\text { week, for } 12 \text { weeks. }\end{array}$ & $\begin{array}{l}\text { 1. Circumference/ Perimeter of } \\
\text { affected limb. }\end{array}$ & $\begin{array}{l}\text { There was a significant } \\
\text { reduction in the circumference } \\
\text { of the affected limb in the } \\
\text { active LLLT group in the } 8^{\text {th }} \\
\text { week }\end{array}$ \\
\hline $\begin{array}{l}\text { Ridner et al. } \\
\text { (2013) }\end{array}$ & 46 & $\begin{array}{l}\text { 1.Group 1: manual lymphatic } \\
\text { drainage for } 40^{\prime}+ \\
\text { compression bandages } \\
\text { 2.Group 2: LLLT + } \\
\text { compression bandages } \\
\text { 3.Group 3: LLLT + manual } \\
\text { lymphatic drainage for 20' }\end{array}$ & $\begin{array}{l}\text { 1. Volume of affected limb } \\
\text { 2. Extracellular fluid } \\
\text { 3. Psychological and physical } \\
\text { symptoms } \\
\text { 4.Quality of Life (QOL) }\end{array}$ & $\begin{array}{l}\text { The volume and extracellular } \\
\text { volume of affected limb, as } \\
\text { well as feeling of heaviness in } \\
\text { limb were reduced. } \\
\text { There were no differences } \\
\text { in the improvement of } \\
\text { psychological and physical } \\
\text { symptoms, or in QOL. } \\
\text { Improved aspect of skin was } \\
\text { reported only by groups that } \\
\text { received LLLT. }\end{array}$ \\
\hline
\end{tabular}

The Omar et al. (24) study associated the LLLT protocol, active and placebo, with a daily upper-limb exercise program, pneumatic and/or inelastic compression, and skin care and hygiene.

The Carati et al. (10) and Lau and Cheing (23) studies presented high methodological quality, scoring 9 and 8 on the PEDro scale, respectively. The Kaviani et al. (11), Ridner et al. (24) and Omar et al. (24) studies were of fair methodological quality and scored 5, 6 and 7, respectively. The average PEDro score of the studies included in this systematic review was 7.0. The most common methodological flaw among them was the lack of intention-to-treat analysis when participants dropped out of the study. The items scored and the total PEDro score for each article are presented in Table 3.

\section{Laser parameters}

Considering the irradiation parameters used, the minimum number of sessions was 9 , the maximum 36, and the protocol was applied for periods varying from 3 to 12 weeks. Carati et al. (10) and Kaviani et al. (11) had an 8-week interval between LLLT cycles. The irradiated regions were the arm, cubital fossa, and armpit, the latter being the most common. Between 5 and 17 treatment points were irradiated in each region. Wavelengths ranged from 808 to $904 \mathrm{~nm}$. The studies employed 1.5 to $2.0 \mathrm{~J} / \mathrm{cm}^{2}$ fluence, with a prevalence of $1.5 \mathrm{~J} / \mathrm{cm}^{2}$. Duration of total LLLT application per session was 17 or 20 minutes. Two studies reported pulse duration and frequency, these being $130 \mathrm{~ns}$ and $3000 \mathrm{~Hz}(11)$ and $50 \mathrm{~ns}$ and $2800 \mathrm{~Hz}$ (24). Laser power varied from $5 \mathrm{mw}(10,24)$ to $24 \mathrm{mw}$ (23). All studies used infrared laser, predominantly of the Gallium Arsenide (GaAs) type. The longest study timeframe was that of Ridner et al. (24), which had participants monitored for a period of 30 months, followed by Carati et al. (10) and Omar et al. (24), who monitored participants for 3 months. Table 4 presents the LLLT laser parameters in detail for each study. 


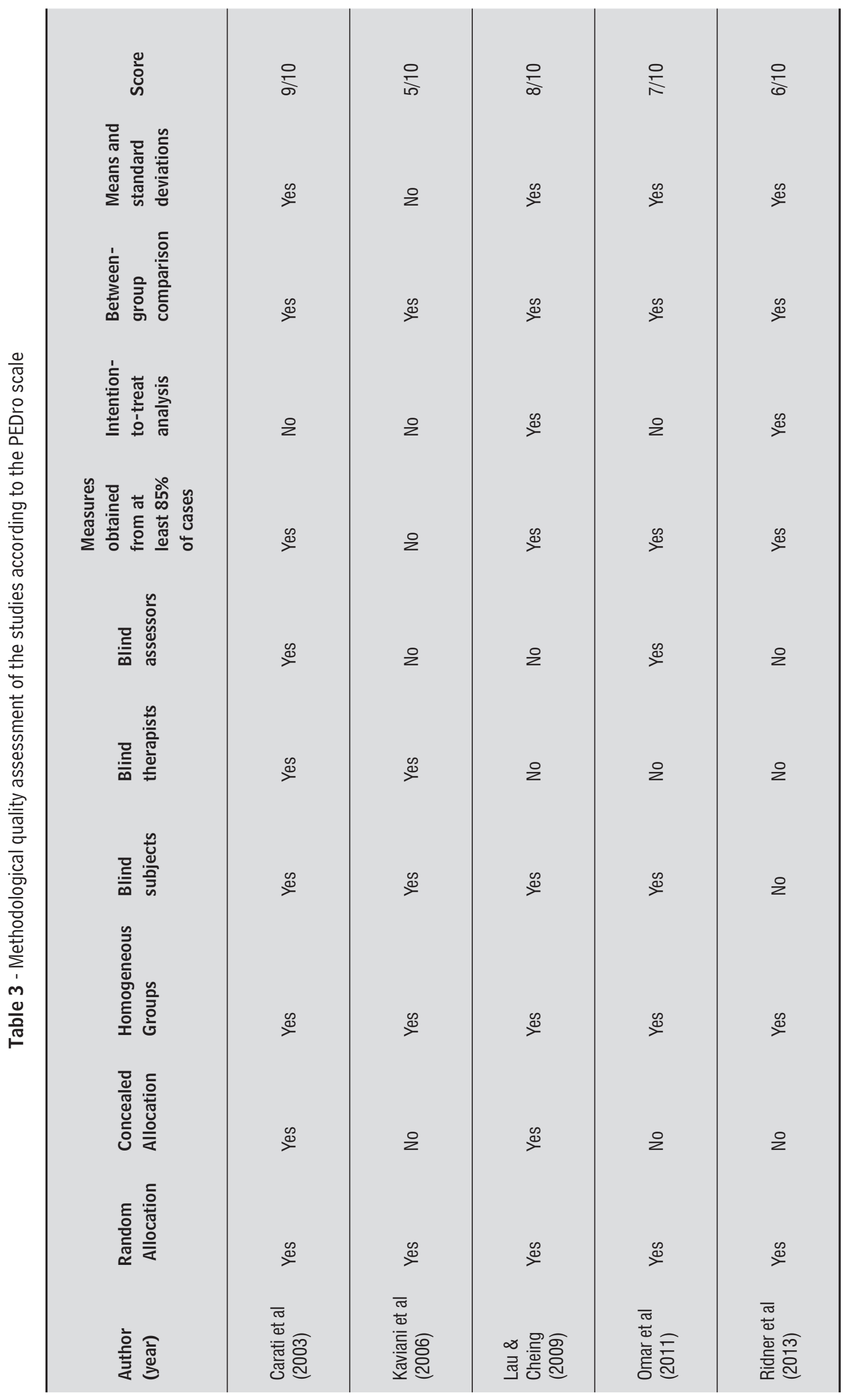


Table 4 - Literature search protocol in Pubmed, PEDro and Lilacs databases

\begin{tabular}{|c|c|c|c|c|c|}
\hline Author (Year) & Protocol & Irradiated region & Wavelength (nm) & $\begin{array}{l}\text { Energy density } \\
\left(\mathrm{J} / \mathrm{cm}^{2}\right)\end{array}$ & $\begin{array}{l}\text { Time/session } \\
\text { (min.) }\end{array}$ \\
\hline Carati et al. (2003) & $\begin{array}{l}9 \text { sess. } 3 \text { weeks, } 3 \\
\text { times/week. } \\
\text { 3-month follow-up }\end{array}$ & 17 armpit points & 904 & 1.5 & $\begin{array}{l}17 \text { (1 min. each } \\
\text { point) }\end{array}$ \\
\hline $\begin{array}{l}\text { Kaviani et al. } \\
\text { (2006) }\end{array}$ & $\begin{array}{l}18 \text { sess. } 3 \text { weeks, } \\
3 \text { times/week. } \\
\text { 8-week interval. } \\
\text { Protocol repeated. }\end{array}$ & $\begin{array}{l}\text { Arm and } 5 \text { armpit } \\
\text { points }\end{array}$ & 890 & 1.5 & Not reported \\
\hline $\begin{array}{l}\text { Lau \& Cheing, } \\
\text { (2009) }\end{array}$ & $\begin{array}{l}12 \text { sess. } 4 \text { weeks, } \\
3 \text { times/week. } \\
\text { 4-week follow-up }\end{array}$ & Armpit & 808 and 905 & 2 & 20 \\
\hline Omar et al. (2011) & $\begin{array}{l}36 \text { sess. } 12 \text { weeks, } \\
3 \text { times/week. }\end{array}$ & $\begin{array}{l}3 \text { cubital fossa } \\
\text { points and } 5 \text { armpit } \\
\text { points }\end{array}$ & 904 & 1.5 & $\begin{array}{l}20 \text { (2 min. each } \\
\text { point) }\end{array}$ \\
\hline Ridner et al. (2013) & Not reported & Not reported & 904 & Not reported & $\begin{array}{l}20 \text { (20 to } 30 \mathrm{sec} . \\
\text { on each point) }\end{array}$ \\
\hline
\end{tabular}

\section{Discussion}

Lymphedema is defined as a chronic swelling due to an insufficiency of the lymphatic system, causing an abnormal retention of fluids rich in proteins in the interstitial space $(8,9)$. The literature, however, lacks consensus on how swollen a region must be to be classified as lymphedema. The same was observed in this review, for there were variations in the quantification of lymphedema measurement methods. One study included only participants with a volume difference greater than $200 \mathrm{ml}$ between limbs (23) and the other four included participants with a difference between limbs greater than 2 centimeters (10, $11,24)$. Omar et al. (24) considered that the difference between limb perimeters should fall between 2 and 8 centimeters, as they defined that their sample would not include severe lymphedema. This variability interfered in the process of re-evaluating effectiveness of treatment and was an obstacle for comparison among studies. Volumetry, which has been considered one of the most sensitive techniques for assessing lymphedema, was used in only one of the studies (23). Notwithstanding, the results of the present study provide a scientific basis for the beneficial effects of LLLT in women with lymphedema following breast cancer surgery. All the articles included in this review (whose methodological quality ranged from fair to high) resulted in reduced circumference or volume of the affected limb after LLLT. However, results regarding pain were not consistent. Response to pain is highly individual and can be affected by several factors, such as previous experiences with pain and cultural and social factors. Not only it is related to what a person feels, that is, the intensity of the perceived pain, but also to the impact on the individual, or in other words, how one reacts to pain. This fact can explain the inconsistency of the effects of LLLT on the pain observed in the reviewed studies.

Light has been used as a source that promotes biological effects since ancient times. Currently, low-level light devices $(<500 \mathrm{~mW})$ - lasers and LEDs - have been widely used in the treatment of a great variety of acute and chronic problems, such as musculoskeletal injuries $(26,27)$, edemas $(28)$, ulcers $(29)$ and autoimmune diseases (30). Nonetheless, their application in the management of lymphedema following breast cancer surgery is still recent and often based on empirical evidence.

In the 1990s, Piller and Thelander were the first researchers to investigate the effects of LLLT on women affected by postmastectomy upper-limb lymphedema $(21,25)$. These authors observed that women submitted to LLLT presented reduced limb volume as well as improvement of symptoms related to this disorder (pain, feeling of heaviness). Despite the positive results and the historical relevance of these studies (which investigated a new therapeutic 
option for upper-limb lymphedema), their weak methodological quality did not guarantee the reliability of their findings. Thus, further studies on the theme are clearly necessary.

According to the literature, the spectrum of electromagnetic radiation for which there are records of therapeutic effects with low-level sources of light encompasses visible to near-infrared wavelengths $(630-1000 \mathrm{~nm})$. The physiological effects caused by light therapy, such as increased cellular activity both in division and synthesis stages are related, however, not only to wavelength, but also to doses $\left(0.04\right.$ to $\left.50 \mathrm{~J} / \mathrm{cm}^{2}\right)$ and power density $\left(10 \mathrm{~W} / \mathrm{cm}^{2}\right)$, as well as the frequency of treatment and type of injury/tissue condition submitted to treatment $(4,31)$.

Some studies reported that another important factor in determining the beneficial effects of light was the time elapsed after irradiation $(32,33,34)$. Cell excitation can be observed anywhere between 1 to 24 hours after irradiation, when doses between 0.01 and $12 \mathrm{~J} / \mathrm{cm}^{2}$ are applied $(34,35,36)$.

In the present study, the best results of light on lymphedema were observed after three months of LLLT. One possible explanation for this fact is that re-establishing the functionality of the lymphatic vessel network requires at least that length of time. However, further studies are needed to confirm this hypothesis.

Carati et al.(10) observed that after three months of follow-up, there was a $90 \mathrm{ml}$ reduction in upperlimb volume and improved quality of life in the group that received active LLLT. Furthermore, Kaviani et al. (11) concluded that in addition to reducing arm circumference, LLLT motivated patients to continue with treatment.

Regarding LLLT protocol, all the studies used the infrared spectral range of light and employed fluences ranging from 1.5 to $2 \mathrm{~J} / \mathrm{cm}^{2}$. The literature advocates that wavelengths in the near infrared spectral range are the most recommended for treating more deeply located structures due to their greater capacity of tissue penetration (37). Moreover, fluences below $8-10 \mathrm{~J} / \mathrm{cm}^{2}$ are said to be capable of promoting the migration and proliferation of restorative cells and those of the immune system $(35,36,38)$. There was no uniformity among the studies regarding the number of sessions, which ranged from 9 to 26, and duration of therapy, which occurred in periods spanning 3 to 12 weeks. This makes it difficult to establish a protocol to be used in clinical practice and also to compare the reviewed studies.

Studies have shown that low-level light favors tissue-healing processes (39), facilitates edema drainage (15), reduces pain (40) and increases defense cell activity (41). Among the suggested hypotheses that explain the effects of LLLT in lymphatic system pathologies are: the stimulation of fibroblasts, macrophages and lymphocytes $(10,23,24)$; reestablishing drainage by forming new vessels, reducing fibrosis and tissue scarring in the armpit region and improving lymphatic vessel contractility $(11,12)$.

According to the literature, within the appropriate parameters and conditions, light therapy seems to promote and/or regulate metabolic processes that clinically result in tissue repair and pain relief. This type of treatment is based on the ability of red or near infrared spectrum light to directly or indirectly alter cellular metabolism as a consequence of being absorbed by photoreceptors - known as chromophores - present in the cells (42). The chief physiological effects of light-tissue interaction are augmented ATP production, increased proliferation of fibroblasts and collagen synthesis, increased RNA and DNA synthesis, angiogenesis stimulation and alterations to afferent nociceptors (43).

Karu (31) reported that the therapeutic effects caused by low-level light therapy are due to primary and secondary mechanisms of action. The primary actions (generation of singlet oxygen, changes in the redox properties of the $\mathrm{CuA}$ and $\mathrm{CuB}$ or heme a and heme a 3 centers and increased superoxide anion production) occur during irradiation, acting directly on the photoreceptor molecules, and their effects can be observed soon after irradiation (31). Secondary mechanisms, on the other hand, (responsible for the connection between the reaction to light by the photoreceptors located in the mitochondria and DNA and RNA synthesis mechanisms located in the nucleus) occur hours or even days after the procedure, as they are dependent on the primary reactions (43).

Factors such as light fluence and intensity used can favor the predominance of one mechanism or the other. Moreover, the photobiomodulation effect also depends on the physiological condition of the cell at the moment of irradiation, as cells with reduced redox potential, as is the case in pathological conditions, are more sensitive to irradiation. Cells in homeostasis react little or not at all to phototherapy and thus its effects are not always detectable (31). 
Even though the articles included in this review were randomized clinical trials, they presented a small number of participants and a relatively short follow-up timeframe (12-month maximum). Thus, the long-term effects of this therapy remain unknown.

One limitation of this review was the reduced number of studies analyzed. There is a scarcity of randomized clinical trials of high methodological quality that investigate the effects of LLLT on lymphedema treatment among women submitted to breast cancer surgery. There is also a lack of studies comparing this therapy with other lymphedema treatment options.

\section{Conclusion}

The use of LLLT in women with upper-limb lymphedema following breast cancer surgery displayed positive results, such as reduction in circumference of volume of the affected limb. Thus, it can be considered one more therapeutic option for managing this condition.

More studies of high methodological quality are needed to better define this therapy, regarding the effects of LLLT on the lymphatic system and in treating upper-limb lymphedema, standardizing protocols and establishing duration of treatment effects following the intervention. Furthermore, studies that investigate the effects of LLLT on the symptoms and functionality of women affected by this health condition are also necessary.

\section{References}

1. Halsted W. The results of operations for the cure of cancer of the breast performed at the Johns Hopkins Hospital from June, 1889 to January, 1894. Ann Surg. 1894;20(5):497-555.

2. Silva HM, Rocha ML, Ferrari BL, Marinho RM. Considerações sobre as doenças da mama. In: Baracho E. Fisioterapia aplicada à obstetrícia, uroginecologia e aspectos de mastologia. Rio de Janeiro: Guanabara Koogan; 2007. p. 523-54.

3. Monteiro SE, Resende LV. Abordagem fisioterapêutica em mastologia oncológica In: Baracho E, organizadora. Fisioterapia aplicada à saúde da mulher. Rio de Janeiro: Guanabara Koogan; 2012. p. 402-4.
4. Monteiro SE. Fisioterapia no pós-operatório de câncer de mama. In: Baracho E. Fisioterapia aplicada à obstetrícia, uroginecologia e aspectos de mastologia. Rio de Janeiro: Guanabara Koogan; 2007. p. 555-68.

5. Jimenez HA. Avaliação funcional e investigação do linfedema após tratamento do câncer de mama. In: Lucena CM; Silva GJ; Barra A. Propedêutica em mastologia. Rio de Janeiro: Guanabara Koogan; 2005. p. 487-514.

6. Megens AM, Harris SR. Physical therapist management of lymphoedema following treatment of breast cancer: a critical review of its effectiveness. Phys Ther. 1998;78(12):1302-11.

7. Petrek JA, Senie RT, Peters M, Rosen PP. Lymphedema in a cohort of breast carcinoma survivors 20 years after diagnosis. J Am Cancer Soc. 2001;92(6):1368-77.

8. Moseley AL, Carati CJ, Piller NB. A systematic review of common conservative therapies for arm lymphoedema secondary to breast cancer treatment. Ann Oncol. 2007;18(4):639-46.

9. International Society of Lymphology Executive Committee. The diagnosis and treatment of peripheral lymphedema. Consensus document of the International Society of Lymphology. Lymphology. 2009; 42(2):51-60.

10. Carati CJ, Anderson SN, Gannon BJ, Piller NB. Treatment of postmastectomy lymphedema with low-level laser therapy: a double blind, placebo-controlled trial. Cancer. 2003;98(6):1114-22.

11. Kaviani A, Fateh M, Nooraie RY, Alinagizadeh MR, Ataie-Fashtami L. Low-level laser therapy in management of postmastectomy lymphedema. Lasers Med Sci. 2006;21(2):90-4.

12. Dirican A, Andacoglu O, Johnson R, McGuire K, Mager L, Soran A. The short-term effects of low-level laser therapy in the management of breast-cancerrelated lymphedema. Support Care Cancer. 2011; 19(5):685-90.

13. Lievens, PC. The influence of laser-irradiation on the motoricity of the lymphatical system and on the wound healing process. In: Proceedings of the 2nd International Congress on Laser in Medicine and Surgery, 1985 June, Locarno; Switzerland. p. 171-174. 
14. Lievens PC. Effects of laser treatment on the lymphatic system and wound healing. J Eur Med Laser Ass. 1988;1(2):12.

15. Lievens, PC. The effect of combined HeNe and I.R. laser treatment on the regeneration of the lymphatic system during the process of wound healing. Lasers Med Sci. 1991;6(2):193-9.

16. Young PE, Baldis HA, Johnston TW, Kruer WL, Estabrook KG. Filamentation and second-harmonic emission in laser-plasma interactions. Phys Rev Lett. 1989;63(26):2812-15.

17. Tadakuma T. Possible application of the laser in immunobiology. Keio J Med. 1993;42(4):180-2.

18. Verhagen AP, Vet HC, Bie RA, Kessels AG, Boers M, Bouter LM, et al. The Delphi list: a criteria list for quality assessment of randomised clinical trials for conducting systematic reviews developed by Delphi consensus. J Clin Epidemiol. 1998;51(12):1235-41.

19. Tunér J, Hode L. The laser therapy handbook. Tallinn: Prima Books AB; 2004.

20. Kozanoglu E, Basaran S, Paydas S, Sarpel T. Efficacy of pneumatic compression and low-level laser therapy in the treatment of postmastectomy lymphedema: a randomized controlled trial. Clin Rehabil. 2009;23(2):117-24.

21. Piller N, Thelander A. Treating chronic post mastectomy lymphoedema with low-level laser therapy: a 2.5 year follow-up. Lymphology. 1998;31(2):74-86.

22. Ridner SH, Poage-Hooper E, Kanar C, Doersam JK, Bond SM, Dietrich MS. A pilot randomized trial evaluating low-level laser therapy as an alternative treatment to manual lymphatic drainage for breast cancer-related lymphedema. Oncol Nurs Forum. 2013;40(4):383-93.

23. Lau RW, Cheing GL. Managing postmastectomy lymphedema with low-level laser therapy. Photomed Laser Surg. 2009;27(5):763-9.

24. Omar MT, Morsy AM, Ebid A. Treatment of postmastectomy lymphedema with laser therapy: double blind placebo control randomized study. J Surg Resea. 2011;165(1):82-90.
25. Piller N, Thelander A. Treating chronic post-mastectomy lymphoedema with low level laser therapy: a cost effective strategy to reduce severity and improve the quality of survival. Laser Ther. 1995;7(4):163-68.

26. Brosseau L, Wells G, Marchand S, Gaboury I, Stokes B, Morin $\mathrm{M}$, et al. Randomized controlled trial on lowlevel laser therapy (LLLT) in the treatment of osteoarthritis (OA) of the hand. Lasers Surg Med. 2005; 36(3):210-9.

27. Tumilty S, Munn J, McDonough S, Hurley DA, Basford JR, Baxter GD. Low-level laser treatment of tendinopathy: a systematic review with meta-analysis. Photomed Laser Surg. 2010;28(1):3-16.

28. Stergioulas A. Low-level laser treatment can reduce edema in second degree ankle sprains. J Clin Laser Med Surg. 2003;22(2):125-8.

29. Schindl A, Schindl M, Pernerstorfer-Schön H, Mossbacher U, Schindl L. Low intensity laser irradiation in the treatment of recalcitrant radiation ulcers in patients with breast cancer: long-term results of 3 cases. Photodermatol Photoimmunol Photomed. 2000;16(1):34-7.

30. Oliveira RG, Aarestrup FM, Miranda C, Vieira BJ, Ferreira AP, Andrade LC. Low-level laser therapy reduces delayed hypersensitivity reaction to ovalbumin in Balb/C mice. Photomed Laser Surg. 2010;28(6): 773-7.

31. Karu TI. Photobiological fundamentals of low-power laser therapy. IEEE J Quantum Electron. 1987;23(10): 1703-17.

32. Khandra M, Lyngstadaas SP, Haanaes HR, Mustafa K. Determining optimal dose of laser therapy for attachment mining optimal dose of laser therapy for attachment and proliferation of human oral fibroblasts cultured on titanium implant material. J Biomed Master Res. 2005;73(1):55-62.

33. Stein A, Benayahu D, Maltz L, Oron U. Low-level laser irradiation promotes proliferation and differentiation of human osteoblasts in vitro. Photomed Laser Surg. 2005;23:161-6.

34. Dourado DM, Favero S, Baranauskas V, Cruz-Hofling MA. Effects of the Ga-As laser irradiation on myonecrosis caused by Bothrops Moojeni snake venom. Lasers Surg Med. 2003;33(5):352-7. 
35. Boulton M. HeNe laser stimulation of human fibroblasts and attachment in vitro. Lasers Life Sci. 1986;1:125-134.

36. Webb C, Dyson M, Lewis WH. Stimulatory effect of $660 \mathrm{~nm}$ low-level laser energy on hypertrophic scar derived fibroblasts: Possible mechanisms for increase cell count. Lasers Surg Med. 1998;22(5):294-301.

37. Ryan T, Smith R. An investigation into the depth of penetration of low level laser therapy through the equine tendon in vivo. I Vet J. 2007;60(5):295-9.

38. Loevschall H, Arneholt-Bindslev D. Effect of low level diode laser irradiation of human oral mucosa fibroblasts in vitro. Lasers Surg Med. 1994;14(4):347-54.

39. Hawkins D, Houreld N, Abrahamse H. Low level laser therapy (LLLT) as an effective therapeutic modality for delayed wound healing. Ann NY Acad Sci. 2005;1056(1):486-93.

40. Hopkins JT, McLoda TA, Seegmiller JG, Baxter GD. Low-level laser therapy facilitates superficial wound healing in humans: a triple-blind, sham-controlled study. J Athl Train. 2004;39(3):223-9.
41. Posten W, Wrone DA, Dover JS, Arndt KA, Silapunt S, Alam M. Low-level laser therapy for wound healing: mechanism and efficacy. Dermatol Surg. 2005;31(3):334-40.

42. Desmet KD, Paz DA, Corry JJ, Eells JT, Wong-Riley MT, Henry MM, et al. Clinical and experimental applications of NIR-LED photobiomodulation. Photomed Laser Surg. 2006;24(2):121-8.

43. Karu TI. Primary and secondary mechanisms of action of visible to near-IR radiation on cells. J Photochem Photobiol B. 1999;49(1):1-17.

Received: 04/02/2014

Recebido: 02/04/2014

Approved: 10/15/2014

Aprovado: 15/10/2014 